\title{
Development of compressive strength of HPC with the use of supplementary cementing material (SCM) combination
}

\author{
AdorJÁn BOROSNYÓI - BME Dept. of Construction Materials and Technologies \\ - borosnyoi.adorjan@epito.bme.hu
}

Érkezett: 2015. 08. 03. - Received: 03. 08. 2015. - http://dx.doi.org/10.14382/epitoanyag-jsbcm.2015.18

\begin{abstract}
The effect of individual or combined use of silica based and alumino-silicate based supplementary cementing materials on the development of the compressive strength of concretes were studied. Most important aim was to reveal if there is any advantage of the combined use of two supplementary cementing materials. Laboratory tests were carried out on standard cube specimens at the age up to 300 days. Results revealed that the two SCMs could not necessarily contribute to a more effective performance in compressive strength, in the studied mixing ratios. Keywords: supplementary cementing material, concrete, compressive strength
\end{abstract}

\section{Introduction}

Durability, recycling potential, large range of performance and low material cost makes concrete to be one of the most widely used construction materials [1-5]. Environmental influences may, however, result the electrochemical corrosion of steel reinforcement and the physical or chemical degradation of concrete. Hydraulic and pozzolanic supplementary cementing materials (SCM) are widely used for a long time to enhance the durability of concrete and hinder reinforcement corrosion [6-16]. Development of SCMs is still continuous today. In the variety of silica and/or alumina based SCMs available for concrete, silica fume ( $>99 \%$ silica) and different purity metakaolins (alumino-silicate minerals) are considered to be the most effective in improving the durability of concrete.

Silica fume (SF) is a by-product of the smelting process in the silicon and ferrosilicon industry [9-10]. Silica fume particles are very small; usually more than $95 \%$ of the particles have lower diameter than $1 \mu \mathrm{m}$. Silica fume is a reactive pozzolanic material due to the small particle size and the very high content of amorphous silica. Silica fume forms $\mathrm{CSH}$ gel with the $\mathrm{Ca}(\mathrm{OH})_{2}$ content of concrete and develops similar hydrate products to that of Portland cement but results much smaller crystal products. Mechanical properties of concrete are improved by the use of silica fume; if superplasticizer admixtures are utilized, high compressive strength of 100 to $150 \mathrm{MPa}$ can be reached. However, due to the different rate of the chemical reactions, the development of the compressive strength in time is different from that of realized for Portland cement.

It is demonstrated in the technical literature that aluminosilicate and calcium-alumino-silicate materials can be used as supplementary cementing materials almost as successfully as silica fume. Typical materials are: ground granulated blastfurnace slag (GGBS), fly ash (FA), metakaolin (MK), natural pozzolans, waste glass powder (WGP), cement kiln dust (CKD), rice husk ash (RHA), paper sludge ash (PSA), volcanic ash, solid waste ash, wood ash, foundry sand and red mud [614]. The most effective alumino-silicate SCM is the metakaolin
Dr. Adorján BOROSNYól (1974) civil engineer (MSc), PhD, associate professor at the BME Dept. of Construction Materials and Technologies. Main fields of interest: application of non-metallic (FRP reinforcements for concrete structures, bond in concrete, non-destructive testing of concrete. Member of the Hungarian Group of fib and of fib TG 4.1 „Serviceability Models". Corresponding member of RILEM Technical Committee ISC "Non-destructive in situ strength assessment of concrete'.

(MK) with considerable pozzolanic activity $[8,14]$. Metakaolin is manufactured by dehydroxilization (calcination) of kaolinitic clay at a temperature between $500^{\circ} \mathrm{C}$ and $800^{\circ} \mathrm{C}$. Kaolinite is formed into a two dimensional crystal structure during dehydroxilization by breaking down or partial breaking down of the original crystal lattice structure and forming a transition phase that is named metakaolin. Successful dehydroxilization of kaolinitic clay results in a disordered, amorphous condition of metakaolin, which has high pozzolanic activity. Increasing the temperature beyond $500^{\circ} \mathrm{C}$ to $800^{\circ} \mathrm{C}$ results in sintering and the formation of mullite, which is not a reactive form. Major constituents of metakaolin are $\mathrm{SiO}_{2}$ and $\mathrm{Al}_{2} \mathrm{O}_{3}$. This alumino-silicate composition of metakaolin allows chemical reaction with $\mathrm{Ca}(\mathrm{OH})_{2}$ in concrete that forms calcium-silicatehydrate gel as well as calcium-aluminate-hydrate and aluminosilicate-hydrate crystalline phases. Recently, different purity metakaolins are available on the market.

\section{Scope of the study}

In the present experimental research, the effect of both the individual and the combined use of silica based ( $S$ ) and alumino-silicate based (A) supplementary cementing materials on the development of the compressive strength of concretes were studied. Most important aim of the study was to reveal if there is any advantage of the combined use of two supplementary cementing materials. Laboratory tests were carried out on standard cube specimens at the age up to 300 days and the influences of the SCMs were analyzed.

\section{Materials}

Quartz sand and gravel was used for the preparation of concretes (maximum aggregate size $16 \mathrm{~mm}$ ) with CEM I 42.5 
$\mathrm{N}$ Portland cement. The water/binder ratio was selected to be $\mathrm{w} / \mathrm{b}=0.40$ with CEM $+\mathrm{SCM}$ amount of $325 \mathrm{~kg} / \mathrm{m}^{3}$. The targeted consistence of the fresh concrete mixes was $600 \mathrm{~mm}$ flow which was set by polycarboxylate based superplasticizer admixture. Twelve mixes were prepared with different amount of SCMs. For the silica based SCM (that was silica fume slurry) the cement substitution ratio was $3 \mathrm{~m} \%, 5 \mathrm{~m} \%, 10 \mathrm{~m} \%$ and $15 \mathrm{~m} \%$. For the alumino-silicate based SCM (of which main oxide content is: $\mathrm{SiO}_{2}$ 52.96\%; $\mathrm{Al}_{2} \mathrm{O}_{3}$ 41.74\%; $\mathrm{CaO}$ 2.98\%; $\mathrm{Fe}_{2} \mathrm{O}_{3} 0.52 \%$ ) the cement substitution ratio was $10 \mathrm{~m} \%, 17 \mathrm{~m} \%$, $25 \mathrm{~m} \%$ and $33 \mathrm{~m} \%$. For the combined use of the SCMs the following cement substitution ratios were applied: aluminosilicate/silica (A/S) ratio of $7 / 3(\mathrm{~m} \% / \mathrm{m} \%), 12 / 5,17 / 8$ and $25 / 8$ to reach a total cement substitution ratio of $10 \mathrm{~m} \%, 17 \mathrm{~m} \%$, $25 \mathrm{~m} \%$ and $33 \mathrm{~m} \%$, respectively. Specimens were stored under water for 7 days and under laboratory atmosphere afterwards.

\section{Experiments}

The laboratory testing of the specimens has been started at the age of 28 days. Compressive strength tests were performed by a Form+Test universal closed-loop hydraulic testing machine according to EN 12390-3 at a constant loading rate of $11.25 \mathrm{kN} / \mathrm{s}$ on the standard cube specimens (150 mm of size). The tests were repeated at the age of 180 days and 300 days as well. Compressive strength of the specimens were calculated and analysed.

\section{Test results}

Table 1 summarizes the results of compressive strength $\left(f_{\mathrm{c}}\right)$ at 28, 180 and 300 days of age. The test results are represented graphically in Fig. 1 to Fig. 3 at 28, 180 and 300 days of age, respectively. It can be seen that the SCMs influence the compressive strength in different magnitudes and the additional development of the compressive strength at later ages is considerably different, too. At 28 days of age, mixes containing silica based SCM (labelled with S in Fig. 1 to Fig. 3) showed the largest increase in the compressive strength for $3 \mathrm{~m} \%$ cement substitution ratio and the lowest increase in the compressive strength for $15 \mathrm{~m} \%$ cement substitution ratio. On the contrary, at later ages due to the considerable additional development of the compressive strength, the largest increase in the compressive strength was found for $15 \mathrm{~m} \%$ cement substitution ratio and the lowest increase in the compressive strength was found for $3 \mathrm{~m} \%$ cement substitution ratio. Later age strength development for $15 \mathrm{~m} \%$ cement substitution ratio is $f_{\mathrm{cm}, 300 \mathrm{~d}} / f_{\mathrm{cm}, 28 \mathrm{~d}}=123.39 \mathrm{MPa} / 104.09 \mathrm{MPa}=1.18$ while the same for $3 \mathrm{~m} \%$ cement substitution ratio is $f_{\mathrm{cm}, 300 \mathrm{~d}} / f_{\mathrm{cm}, 28 \mathrm{~d}}$ $=113.54 \mathrm{MPa} / 108.02 \mathrm{MPa}=1.05$. At 28 days of age, mixes containing alumino-silicate based SCM (labelled with A in Fig. 1 to Fig. 3) showed the largest increase in the compressive strength for $10 \mathrm{~m} \%$ cement substitution ratio and the lowest increase in the compressive strength for $33 \mathrm{~m} \%$ cement substitution ratio. This difference did not change at later ages. Later age strength development for $10 \mathrm{~m} \%$ cement substitution ratio is $f_{\mathrm{cm}, 300 \mathrm{~d}} / f_{\mathrm{cm}, 28 \mathrm{~d}}=121.07 \mathrm{MPa} / 110.42 \mathrm{MPa}=1.10$ while the same for $33 \mathrm{~m} \%$ cement substitution ratio is $f_{\mathrm{cm}, 300 \mathrm{~d}} / f_{\mathrm{cm}, 28 \mathrm{~d}}$

\begin{tabular}{|c|c|c|c|c|}
\hline & \multicolumn{3}{|c|}{ Compressive strength, $\mathrm{f}_{\mathrm{c}}\left(\mathrm{N} / \mathrm{mm}^{2}\right)$} & pH value \\
\hline & 28 days & 180 days & \multicolumn{2}{|c|}{300 days } \\
\hline \multicolumn{5}{|c|}{ Reference mix } \\
\hline CEM & 81.71 & 89.51 & 92.45 & 12.09 \\
\hline \multicolumn{5}{|c|}{ Mixes with silica based SCM } \\
\hline S3 & 108.02 & 110.76 & 113.54 & 12.01 \\
\hline S5 & 107.00 & 111.96 & 115.53 & 11.96 \\
\hline $\mathbf{S 1 0}$ & 109.27 & 119.96 & 122.46 & 11.89 \\
\hline S15 & 104.09 & 117.36 & 123.39 & 11.81 \\
\hline \multicolumn{5}{|c|}{ Mixes with alumino-silicate based SCM } \\
\hline A10 & 110.42 & 119.53 & 121.07 & 12.0 \\
\hline A17 & 105.13 & 110.47 & 113.33 & 11.92 \\
\hline A25 & 102.76 & 108.27 & 109.25 & 11.9 \\
\hline A33 & 100.80 & 103.16 & 106.12 & 11.87 \\
\hline \multicolumn{5}{|c|}{ Mixes with combined use of A/S SCMs } \\
\hline $7 / 3$ & 89.64 & 106.20 & 115.87 & 12.04 \\
\hline $12 / 5$ & 90.60 & 101.62 & 104.08 & 11.98 \\
\hline $17 / 8$ & 91.29 & 98.78 & 101.44 & 11.87 \\
\hline $25 / 8$ & 84.73 & 93.56 & 98.77 & 11.84 \\
\hline
\end{tabular}

Table 1. Experimental results

1. táblázat Experimental results

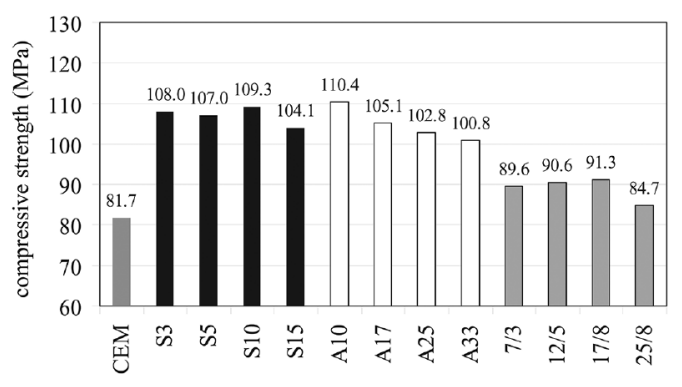

Fig. 1. Mean compressive strength of concrete specimens at 28 days of age 1. ábra Átlagos beton nyomószilárdságok 28 napos korban

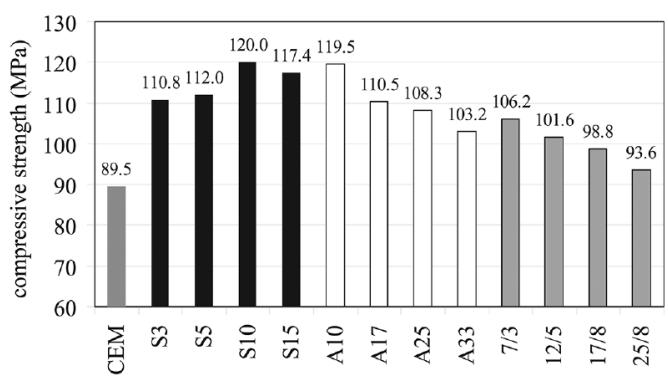

Fig. 2. Mean compressive strength of concrete specimens at 180 days of age 2. ábra Átlagos beton nyomószilárdságok 180 napos korban

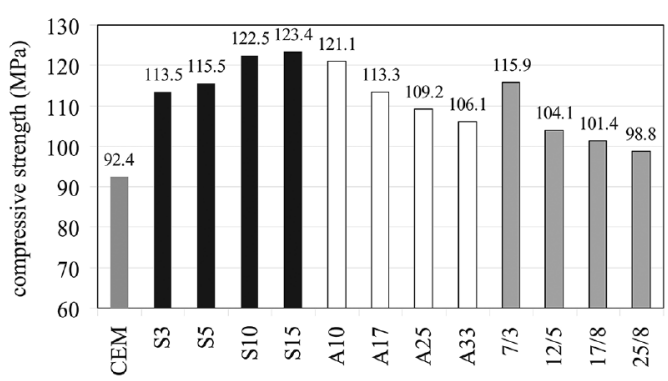

Fig. 3. Mean compressive strength of concrete specimens at 300 days of age 3. ábra Átlagos beton nyomószilárdságok 300 napos korban 


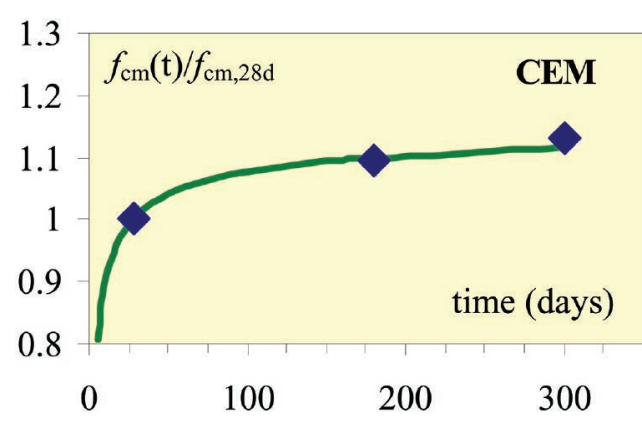

Fig. 4. Development of compressive strength in time; reference mix 4. ábra Referencia keverék nyomószilárdságának időbeli fejlődése
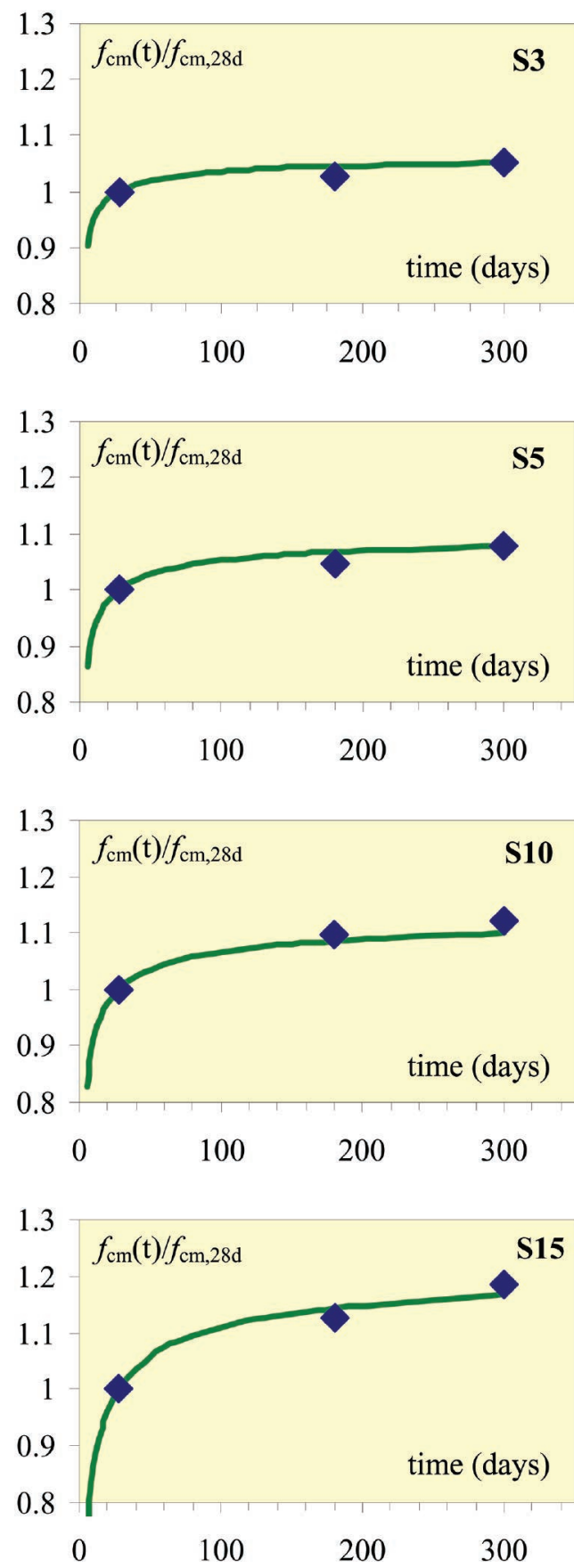

Fig. 5. Development of compressive strength in time; mixes with silica based SCM 5. ábra Keverékek nyomószilárdságának időbeli fejlödése szilikát bázisú kiegészitőanyaggal
$=106.12 \mathrm{MPa} / 100.80 \mathrm{MPa}=1.05$. It can be found for the mixes containing both silica based (S) and alumino-silicate based (A) supplementary cementing materials that the alumino-silicate SCM governs the overall behaviour: the more the amount of SCM, the less the increase in the compressive strength. The most pronounced later age strength development corresponds to the mixes with alumino-silicate/silica (A/S) ratio of $7 / 3(\mathrm{~m} \% / \mathrm{m} \%)$, with $f_{\mathrm{cm}, 300 \mathrm{~d}} / f_{\mathrm{cm}, 28 \mathrm{~d}}=115.87 \mathrm{MPa} / 89.64 \mathrm{MPa}=1.29$ while the same for $\mathrm{A} / \mathrm{S}=25 / 8$ is $f_{\mathrm{cm}, 300 \mathrm{~d}} / f_{\mathrm{cm}, 28 \mathrm{~d}}=98.77 \mathrm{MPa} / 84.73 \mathrm{MPa}=$ 1.17. For comparison, the later age strength development for the reference mix is $f_{\mathrm{cm}, 300 \mathrm{~d}} / f_{\mathrm{cm}, 28 \mathrm{~d}}=92.45 \mathrm{MPa} / 81.71 \mathrm{MPa}=$ 1.13 .

Time development of $f_{\mathrm{cm}}(\mathrm{t}) / f_{\mathrm{cm}, 28 \mathrm{~d}}$ ratios are indicated in Fig. 4 to Fig. 7 and values of $f_{\mathrm{cm}, 300 \mathrm{~d}} / f_{\mathrm{cm}, 28 \mathrm{~d}}$ ratios are indicated in Fig. 8 for the concrete mixes studied in the present research.

\section{Discussion}

The compressive strength of concrete at an age $t$ depends on the type and strength class of the cement, the type and amount of admixtures and additions, the water/cement ratio and environmental conditions, such as temperature and humidity [17]. For a mean temperature of $20^{\circ} \mathrm{C}$ and curing in accordance with ISO 1920-3 the relevant compressive strength of concrete at various ages $f_{\mathrm{cm}}(\mathrm{t})$ may be estimated from Eq. (1) and (2):

$f_{\mathrm{cm}}(\mathrm{t})=\beta_{\mathrm{cc}}(\mathrm{t}) \cdot f_{\mathrm{cm}, 28 \mathrm{~d}}$

$\beta_{\mathrm{cc}}(\mathrm{t})=\exp \left\{\mathrm{s} \cdot\left[1-\left(\begin{array}{c}28 \\ \mathrm{t}\end{array}\right)^{0.5}\right]\right\}$

where:

$f_{\mathrm{cm}}(\mathrm{t})$ is the mean compressive strength in $\mathrm{MPa}$ at an age $\mathrm{t}$ in days;

$f_{\mathrm{cm}, 28 \mathrm{~d}}$ is the mean compressive strength in $\mathrm{MPa}$ at an age of 28 days;

$\beta_{\mathrm{cc}}(\mathrm{t})$ is a function to describe the strength development with time;

$\mathrm{t}$ is the concrete age in days (taking into account the temperature during curing);

$s \quad$ is a coefficient which depends on the strength class of cement.

Eq. (1) was developed based on results obtained from experiments on structural concrete primarily made with CEM I and CEM III cements [17]. If other cement types are used or if high amounts of pozzolans are used as partial replacement of CEM I, then the development of the compressive strength with time should be determined experimentally. Concretes with a high content of fly ash, natural pozzolans or fine granulated blast furnace slag show a reduced compressive strength at early age and a considerable further strength gain at higher ages [17]. This effect may be more pronounced than considered in Eq. (1) for a low strength, normal hardening cement. Generally, the value for the coefficient $s$ is suggested to be $s=0.38$ for CEM $32.5 \mathrm{~N}$; $\mathrm{s}=0.25$ for CEM $32.5 \mathrm{R}, \mathrm{CEM} 42.5 \mathrm{~N}$; $\mathrm{s}=0.20$ for CEM 42.5 R, CEM 52.5 N, CEM 52.5 R (in accordance with the nomenclature of EN 197-1 European Standard). 

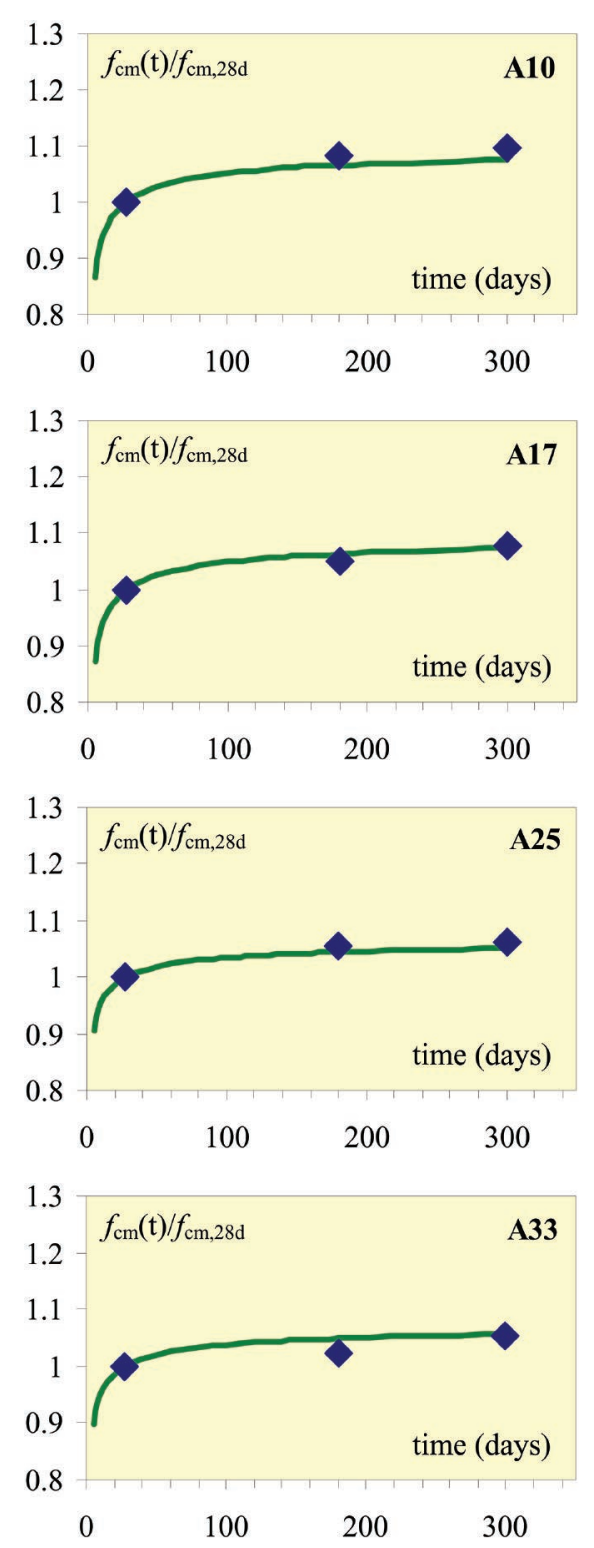

Fig. 6. Development of compressive strength in time; mixes with alumino-silicate based SCM

6. ábra Keverékek nyomószilárdságának időbeli fejlődése alumino-szilikát bázisú kiegészítöanyaggal

The value of coefficient $s$ was determined for the concrete mixes studied in the present research (see Fig. 9). It can be realized that the value of coefficient $s$ for the cement used in this study $(s=0.18)$ is very close to the value suggested by [17] for CEM $42.5 \mathrm{R}(\mathrm{s}=0.20)$, therefore the comparative analysis of coefficient $s$ is reasonable.

It can be realized at the independent use of the silica based SCM that it does not develop full potential by the age of 28 days since the compressive strength of the specimens is almost the same at the age of 28 days, independently of the amount of silica based SCM applied (Fig. 1). It can be seen that the later age strength development needs the availability of calciumhydroxide for the further reactions. Fig. 10 summarizes the $\mathrm{pH}$ values (in percents as well) of the specimens at the age of 300 days. One can see that the $\mathrm{pH}$ of mix S15 specimens is the lowest that indicates high amount of fixed calcium-hydroxide during the hydration process.
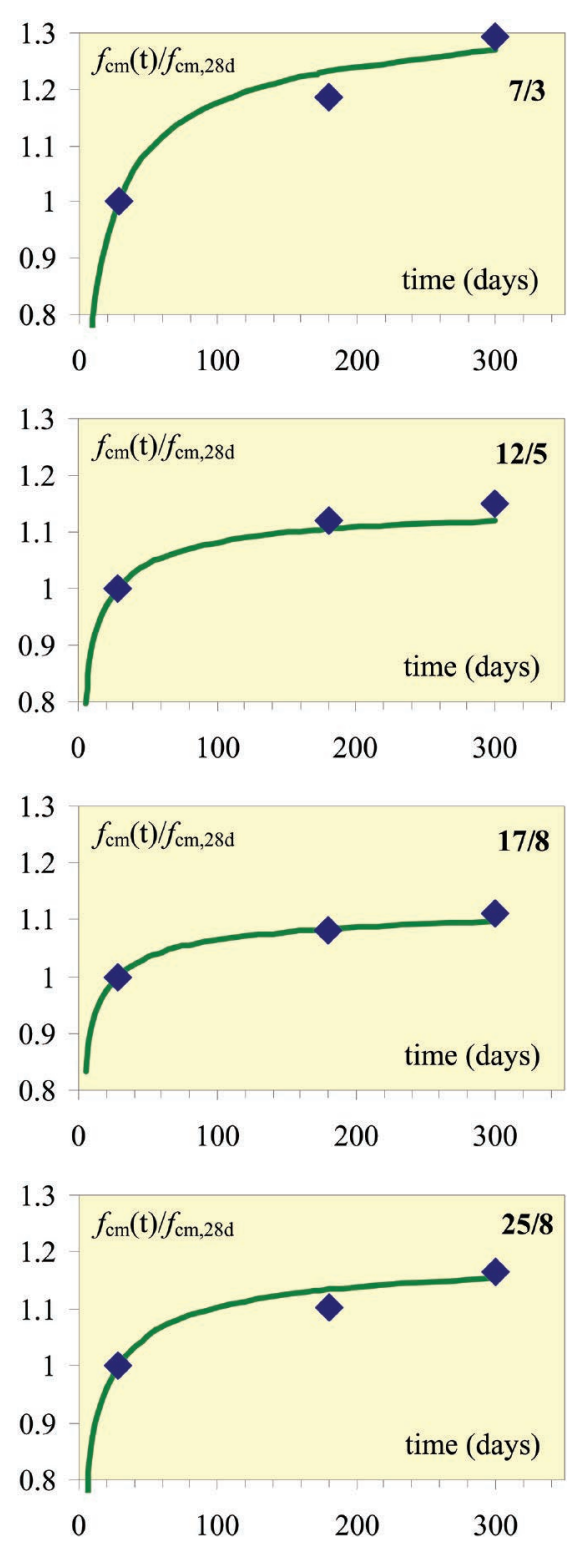

Fig. 7. Development of compressive strength in time; mixes with combined use of SCMs

7. ábra Keverékek nyomószilárdságának időbeli fejlődése a kiegészítőanyagok kombinálása esetén

The alumino-silicate based SCM was applied at large doses during this research. It seems that the effectiveness of the alumino-silicate based SCM is decreasing by increasing its amount throughout the studied range. The more the amount of the alumino-silicate based SCM, the more the fixed calciumhydroxide during the hydration process, however, loss in gain of strength is realized (see Figs. 1 to 3 and Fig. 10). It is also observable that the more the amount of the alumino-silicate based SCM, the less the later age strength development (see decreasing tendency of coefficient s in Fig. 9).

Combined use of the two SCMs is resulted in a complex, rather contradictory behaviour. It can be observed in Fig. 10 that the fixed calcium-hydroxide content is generally less in the cases of mixed use of the two SCMs than that would be expected from the individual use of them, especially when the total amount of the SCM is $10 \%$ or $17 \%$ (mixes $7 / 3$ and $12 / 5)$. In these two cases the later age strength development 
is unexpectedly large (see values of coefficient s in Fig. 9). At doses of $25 \%$ or $33 \%$ total SCM (mixes $17 / 8$ and 25/8) the fixed calcium-hydroxide content is observed at an expected level. It can be seen that mixed use of the two SCMs is resulted in more drop in $\mathrm{pH}$ than that was resulted by the individual application of the alumino-silicate based SCM in the same amount. It seems, however, that the influence of the aluminosilicate based SCM dominates over the influence of the silica based SCM (see Figs. 1 to 3). No clear tendency is seen in the coefficient s (Fig. 9). Further studies are needed to explain the observed behaviour.

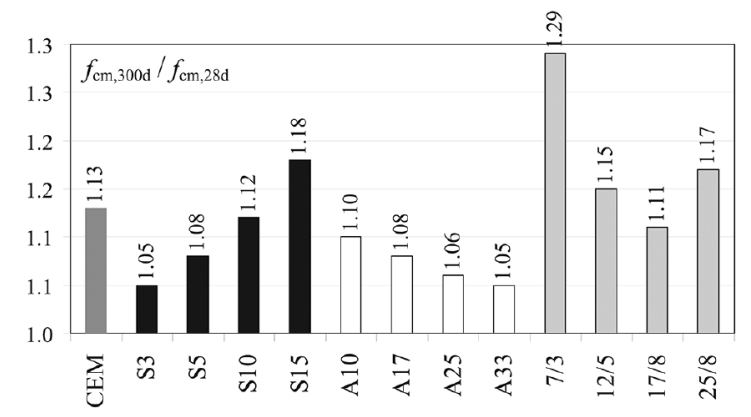

Fig. 8. Values of $f_{c m, 300 d} / f_{c m, 28 d}$ for the studied concrete mixes

8. ábra Az $f_{c m, 300 d} / f_{c m, 28 d}$ arány értékei a vizsgált beton összetételekre

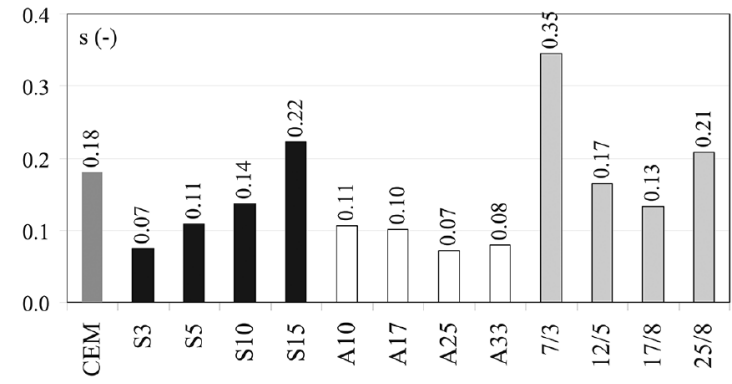

Fig. 9. Values of coefficient s for the studied concrete mixes

9. ábra Az s parameter értékei a vizsgált beton összetételekre

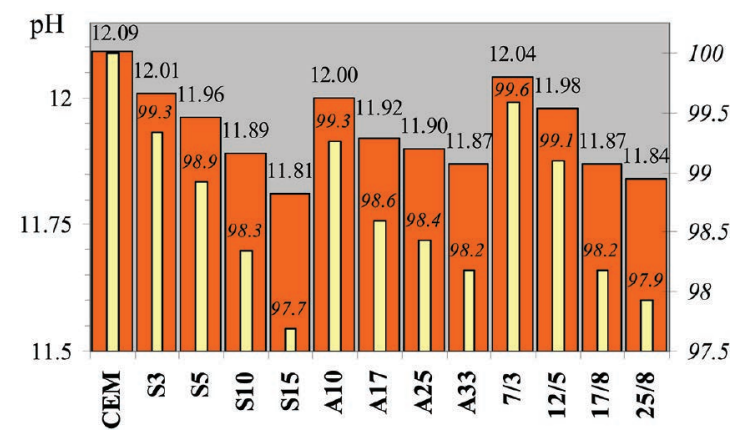

Fig. 10. $p H$-values of studied concrete mixes at the age of 300 days (non carbonated) 10. ábra A vizsgált beton összetételek pH értéke 300 napos korban (nem karbonátosodott részek)

\section{Conclusions}

The present paper has summarized the experimental observations of compressive strength of concretes with large doses of supplementary cementing materials (SCM). During the research, both individual and mixed use of silica based and alumino-silicate based supplementary cementing materials were studied. Most important aim of the study was to reveal if there is any advantage of the mixed use of two supplementary cementing materials. For the silica based SCM (that was silica fume slurry) the cement substitution ratio was $3 \mathrm{~m} \%, 5 \mathrm{~m} \%$, $10 \mathrm{~m} \%$ and $15 \mathrm{~m} \%$. For the alumino-silicate based SCM (of which main oxide content is: $\mathrm{SiO}_{2} 52.96 \% ; \mathrm{Al}_{2} \mathrm{O}_{3} 41.74 \%$; $\mathrm{CaO}$ $2.98 \% ; \mathrm{Fe}_{2} \mathrm{O}_{3} 0.52 \%$ ) the cement substitution ratio was $10 \mathrm{~m} \%$, $17 \mathrm{~m} \%, 25 \mathrm{~m} \%$ and $33 \mathrm{~m} \%$. For the mixed use of the SCMs the following cement substitution ratios were applied: aluminosilicate/silica (A/S) ratio of $7 / 3(\mathrm{~m} \% / \mathrm{m} \%), 12 / 5,17 / 8$ and $25 / 8$ to reach a total cement substitution ratio of $10 \mathrm{~m} \%, 17 \mathrm{~m} \%$, $25 \mathrm{~m} \%$ and $33 \mathrm{~m} \%$, respectively.

The following conclusions can be drawn by the experimental observations:

- Mixes containing silica based SCM showed the largest increase in the compressive strength for $3 \mathrm{~m} \%$ cement substitution ratio and the lowest increase in the compressive strength for $15 \mathrm{~m} \%$ cement substitution ratio. On the contrary, at later ages due to the considerable additional development of the compressive strength, the largest increase in the compressive strength was found for $15 \mathrm{~m} \%$ cement substitution ratio and the lowest increase in the compressive strength was found for $3 \mathrm{~m} \%$ cement substitution ratio.

- Mixes containing alumino-silicate based SCM showed the largest increase in the compressive strength for 10 $\mathrm{m} \%$ cement substitution ratio and the lowest increase in the compressive strength for $33 \mathrm{~m} \%$ cement substitution ratio. This difference did not change at later ages.

- For mixes containing both silica based and aluminosilicate based supplementary cementing materials the alumino-silicate SCM governs the overall behaviour: the more the amount of SCM, the less the increase in the compressive strength.

- The results for the combined use of silica based and alumino-silicate based supplementary cementing materials revealed that the two SCMs could not necessarily contribute to a more effective performance in compressive strength, in the studied mixing ratios. Further research is needed in this field.

\section{Acknowledgements}

The financial support of the Hungarian Scientific Research Fund (OTKA) is highly appreciated (Project No. OTKA T 109223).

\section{References}

[1] Pekár, G. (2013a): Simple basic model for concrete and its application. 1. Content indicators of concrete mixtures and mixing plant observations, Épitöanyag - Journal of Silicate Based and Composite Materials, Vol. 65. No. 2, pp. 52-60. http://dx.doi.org/10.14382/epitoanyag-jsbcm.2013.12

[2] Pekár, G. (2013b): Simple basic model for concrete and its application. 2. Factors that influence compressive strength and drying shrinkage, Épitöanyag - Journal of Silicate Based and Composite Materials, Vol. 65. No. 3, pp. 76-84. http://dx.doi.org/10.14382/epitoanyag-jsbcm.2013.15

[3] Pekár, G. (2013c): Simple basic model for concrete and its application. 3. Factors aff ecting consistency, material balance equations and mix design, Épitöanyag - Journal of Silicate Based and Composite Materials, Vol. 65. No. 4, pp. 118-126. http://dx.doi.org/10.14382/epitoanyag-jsbcm.2013.22 
[4] Nemes, R. - Török, B. (2014): Bond of steel reinforcement in different lightweight aggregate concretes, Épitöanyag - Journal of Silicate Based and Composite Materials, Vol. 66. No. 1, pp. 7-12. (in Hungarian) http://dx.doi.org/10.14382/epitoanyag-jsbcm.2014.2

[5] Nemes, R. (2015): Special topics in the freeze-thaw resistance of lightweight concretes, Épitöanyag - Journal of Silicate Based and Composite Materials, Vol. 67. No. 1, pp. 24-27. (in Hungarian)

http://dx.doi.org/10.14382/epitoanyag-jsbcm.2015.5

[6] Frías, M. - Sánchez de Rojas, M. I. - Cabrera, J. (2000): The effect that the pozzolanic reaction of metakaolin has on the heat evolution in metakaolin-cement mortars, Cement and Concrete Research, Vol. 30, No. 2, pp. 209-216. http://dx.doi.org/10.1016/S0008-8846(99)00231-8

[7] Wong, H. S. - Razak, H. A. (2005): Efficiency of calcined kaolin and silica fume as cement replacement material for strength performance, Cement and Concrete Research, Vol. 35, No. 4, pp. 696-702. http://dx.doi.org/10.1016/j.cemconres.2004.05.051

[8] Siddique, R. - Klaus, J. (2009): Influence of metakaolin on the properties of mortar and concrete: A review, Applied Clay Science, Vol. 43, No. 3-4, pp. 392-400. http://dx.doi.org/10.1016/j.clay.2008.11.007

[9] Khan, M. I. - Siddique, R. (2011): Utilization of silica fume in concrete: Review of durability properties, Resources, Conservation and Recycling, Vol. 57, pp. 30-35. http://dx.doi.org/10.1016/j.resconrec.2011.09.016

[10] Siddique, R. (2011): Utilization of silica fume in concrete: Review of hardened properties, Resources, Conservation and Recycling, Vol. 55, pp. 923-932. http://dx.doi.org/10.1016/j.resconrec.2011.06.012

[11] Hassan, A. A. A. - Lachemi, M. - Hossain, K. M. A. (2012): Effect of metakaolin and silica fume on the durability of self-consolidating concrete, Cement and Concrete Composites, Vol. 34, No. 6, pp. 801-807. http://dx.doi.org/10.1016/j.cemconcomp.2012.02.013

[12] Valipour M. - Pargar F. - Shekarchi M. - Khani S. (2013): Comparing a natural pozzolan, zeolite, to metakaolin and silica fume in terms of their effect on the durability characteristics of concrete: A laboratory study, Construction and Building Materials, Vol. 41, pp. 879-888. http://dx.doi.org/10.1016/j.conbuildmat.2012.11.054

[13] Duan, P. - Shui, Z. - Chen, W. - Shen, C. (2013): Effects of metakaolin, silica fume and slag on pore structure, interfacial transition zone and compressive strength of concrete, Construction and Building Materials, Vol. 44, pp. 1-6. http://dx.doi.org/10.1016/j.conbuildmat.2013.02.075

[14] Rashad, A. M. (2013): Metakaolin as cementitious material: History, scours, production and composition - A comprehensive overview, Construction and Building Materials, Vol. 41, pp. 303-318.

http://dx.doi.org/10.1016/j.conbuildmat.2012.12.001
[15] Nehme, S. G. (2015a): Influence of supplementary cementing materials on conventional and self compacting concretes - Part. 1. Literature review, Épitöanyag - Journal of Silicate Based and Composite Materials, Vol. 67. No. 1, pp. 28-33. (in Hungarian)

http://dx.doi.org/10.14382/epitoanyag-jsbcm.2015.6

[16] Nehme, S. G. (2015b): Influence of supplementary cementing materials on conventional and self compacting concretes - Part. 2. Laboratory tests, Épitöanyag - Journal of Silicate Based and Composite Materials, Vol. 67. No. 2, pp. 71-78. (in Hungarian)

http://dx.doi.org/10.14382/epitoanyag-jsbcm.2015.12

[17] fib (2013) Model Code for Concrete Structures 2010, fédération internationale du béton - International Federation for Structural Concrete (fib), Ernst \& Sohn, 402 p.

$\underline{\text { Ref.: }}$

Borosnyói, Adorján: Development of compressive strength of HPC with the use of supplementary cementing material (SCM) combination Építöanyag - Journal of Silicate Based and Composite Materials, Vol. 67, No. 3 (2015), 110-115. p.

http://dx.doi.org/10.14382/epitoanyag-jsbcm.2015.18

Nagy teljesítőképességű betonok nyomószilárdsága cement kiegészítő anyagok kombinált alkalmazása esetén

A cikk azt vizsgálja, hogy nagy mennyiségben adagolt szilika-bázisú, illetve aluminoszilikát-bázisú cement kiegészítô anyagok hogyan befolyásolják a nagy teljesítôképességú betonok nyomószilárdságát, és a nyomószilárdság idő́beli fejlôdését. A kutatás a cement kiegészítô anyagokat önállóan is, és egymással kombináltan is vizsgálja. Az eredmények rávilágítanak a cement kiegészítô anyagok hatékonyan alkalmazható mennyiségére és az általuk elérhetô teljesítôképesség-növekedés idôbeli alakulására. Az eredmények szerint a cement kiegészítô anyagok nem minden kombinációja vezet kedvezóbb eredményre, mint a cement kiegészítô anyagok önálla alkalmazása.

Kulcsszavak: cement kiegészítô anyagok, beton, nyomószilárdság beton érték generációknak

2015. 09. 30. Bakelit Multi Art $c$ e $n$ t e $r$ 1095 Budapest, Soroksári út 164.

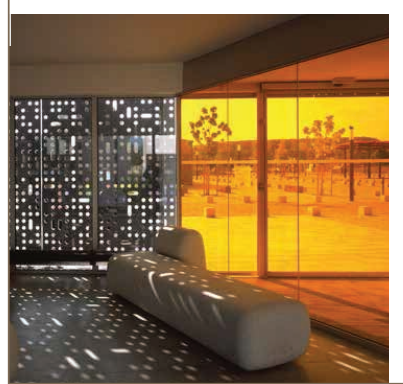

\section{BETON FESZTIVÁL 2015}
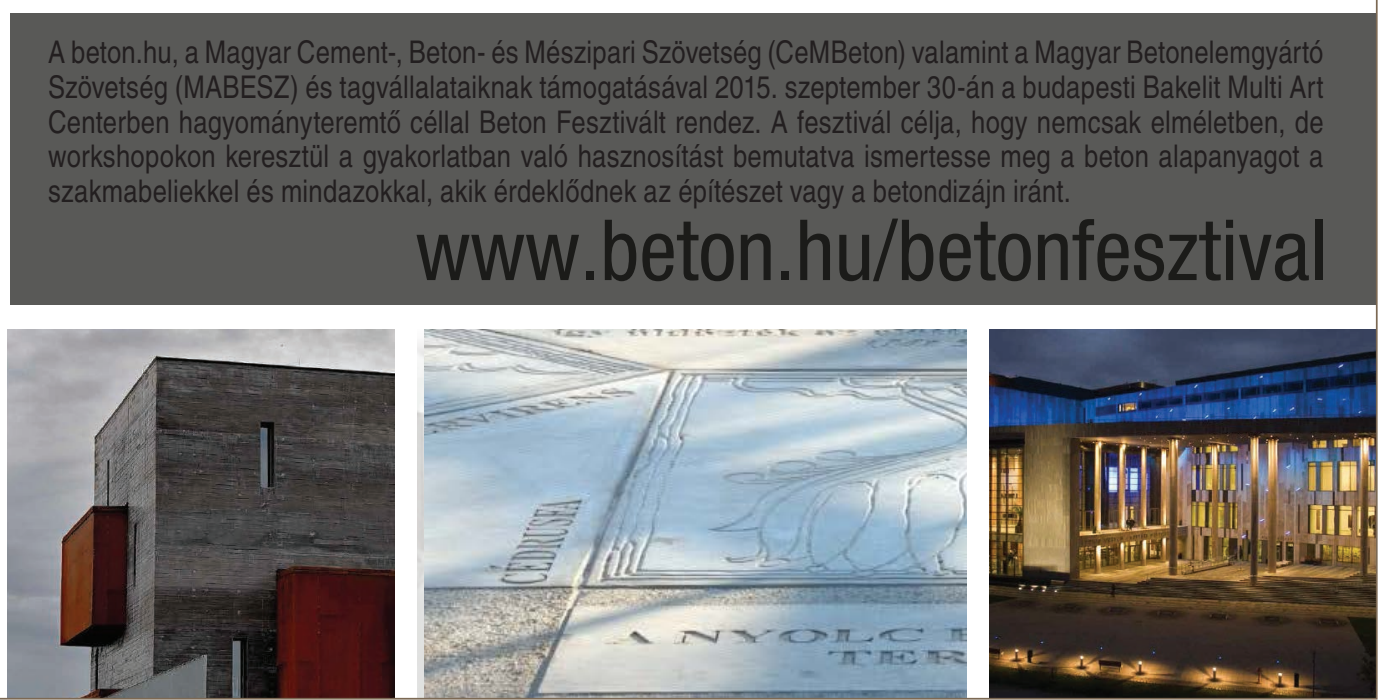